\title{
Successful management with bisphosphonate treatment in a child with tuberculosis-associated hypercalcemia
}

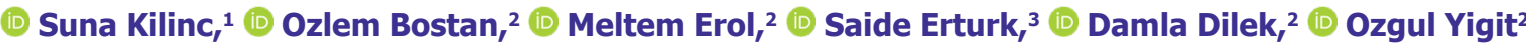 \\ ${ }^{1}$ Department of Pediatric Endocrinology, Istanbul Bagcilar Training and Research Hospital, Istanbul, Turkey \\ ${ }^{2}$ Department of Pediatrics, Istanbul Bagcilar Training and Research Hospital, Istanbul, Turkey \\ ${ }^{3}$ Department of Pediatrics, Istanbul Esenler Obstetrics and Pediatrics Hospital, Istanbul, Turkey
}

\begin{abstract}
Hypercalcemia is a common metabolic abnormality in children and generally occurs due to hyperparathyroidism, vitamin D toxicity, some genetic disorders and malignant diseases. Granulomatous diseases are a rare cause of hypercalcemia in children, which are usually mild and asymptomatic. Severe hypercalcemia in granulomatous diseases has also been reported in the literature. Here, we report a child presenting with severe hypercalcemia secondary to miliary tuberculosis with successful management with bisphosphonate treatment. Increased 1,25(OH)2D3 synthesis by activated macrophages in the granuloma tissue is the major mechanism of hypercalcemia in tuberculosis.
\end{abstract}

Keywords: Bisphosphonates; hypercalcemia; miliary tuberculosis; pamidronate-disodium.

Cite this article as: Kilinc S, Bostan O, Erol M, Erturk S, Dilek D, Yigit O. Successful management with bisphosphonate treatment in a child with tuberculosis-associated hypercalcemia. North Clin Istanb 2020;7(4):411-414.

$\mathrm{H}$ ypercalcemia is a common metabolic abnormality in children. Hyperparathyroidism, vitamin D toxicity and some endocrinopathies are the most frequent causes of hypercalcemia. Granulomatous disorders, such as tuberculosis and sarcoidosis, are a rare cause of hypercalcemia in the childhood period in which is usually mild and asymptomatic $[1,2]$. Severe hypercalcemia in granulomatous diseases has also been reported in the literature. Here, we report a child presenting with severe hypercalcemia and nephrocalcinosis secondary to miliary tuberculosis in whom hypercalcemia resolved with bisphosphonate treatment.

\section{CASE REPORT}

A 16-months-old female patient admitted to our hospital with a 3-days history of fever, fatigue and poor ap- petite. On examination, she was cachectic and lethargic. Height was $63.5 \mathrm{~cm}$ (less than the third percentile), weight was $6.150 \mathrm{~g}$ (less than the third percentile), and head circumference was $45 \mathrm{~cm}$ (3-10 percentile). A systemic examination revealed bilateral coarse crackles throughout both lung fields and hepatosplenomegaly. Laboratory tests are summarized in Table 1 . The total calcium and the ionized calcium levels were elevated $(18.3 \mathrm{mg} / \mathrm{dL}, \mathrm{N}: 9-11 ; 4.57 \mathrm{mmol} / \mathrm{L}, \mathrm{N}: 1.12-1.32$, respectively). The phosphate level was $4.4 \mathrm{mg} / \mathrm{dL}(\mathrm{N}$ : 3.4-6) within the normal range. There was neither a reported history of excessive calcium or vitamin D intake nor consumption of thiazides. Alkaline phosphatase was $131 \mathrm{U} / \mathrm{L}(\mathrm{N}: 5-281)$, 25-hydroxy vitamin D was 133 $\mathrm{ng} / \mathrm{mL}(\mathrm{N}: 30-70)$, and parathyroid hormone level was decreased $1.2 \mathrm{pg} / \mathrm{mL}(\mathrm{N}: 15-65)$. The 1,25-dihydroxyvitamin D3 level was also high at $345 \mathrm{pg} / \mathrm{mL}$ (N: 21-

Received: October 18, 2018 Accepted: May 21, 2019 Online: May 27, 2020

Correspondence: Suna KILINC, MD. Istanbul Bagcilar Egitim ve Arastirma Hastanesi, Cocuk Endokrinoloji Klinigi, Istanbul, Turkey. Tel: +902124404000 e-mail: sunahancili@hotmail.com

(c) Copyright 2020 by Istanbul Provincial Directorate of Health - Available online at www.northclinist.com 
TABLE 1. Biochemical data of relevant laboratory tests performed

\begin{tabular}{lcc} 
Laboratory test & Values & Normal range \\
\hline Haemoglobin $(\mathrm{g} / \mathrm{dL})$ & 9.1 & $10.8-12.6$ \\
Leucocyte $\left(10^{3} \mathrm{~mm}^{3}\right)$ & 15.500 & $7-13$ \\
Platelet $\left(10^{3} \mathrm{~mm}^{3}\right)$ & 636.000 & $130-400$ \\
Urea $(\mathrm{mg} / \mathrm{dL})$ & 37 & $10.7-39$ \\
Creatinine $(\mathrm{mg} / \mathrm{dL})$ & 0.4 & $0.3-0.7$ \\
Sodium $(\mathrm{mmol} / \mathrm{L})$ & 136 & $136-145$ \\
Potassium $(\mathrm{mmol} / \mathrm{L})$ & 3.9 & $3.5-5.1$ \\
Calcium $(\mathrm{mg} / \mathrm{dL})$ & 18.3 & $9-11$ \\
Phosphate $(\mathrm{mg} / \mathrm{dL})$ & 4.4 & $3.4-6$ \\
Magnesium $(\mathrm{mg} / \mathrm{dL})$ & 1.72 & $1.7-2.3$ \\
Alkaline $\mathrm{phosphatase}(\mathrm{U} / \mathrm{L})$ & 131 & $5-281$ \\
Albumin $(\mathrm{g} / \mathrm{dL})$ & 3.9 & $3.8-5.4$ \\
Erythrocyte sedimentation rate $(\mathrm{mm} / \mathrm{h})$ & 72 & $<20$ \\
C-reactive protein $(\mathrm{mg} / \mathrm{L})$ & 45.7 & $0-5$ \\
Procalcitonin $(\mathrm{ng} / \mathrm{mL})$ & 2.5 & $0-0.5$ \\
Urinary ca/cr ratio & 1.25 & $<0.5$ \\
Parathyroid hormone $(\mathrm{pg} / \mathrm{mL})$ & 1.2 & $15-65$ \\
25-hydroxyvitamin $\mathrm{D}(\mathrm{ng} / \mathrm{mL})$ & 133 & $30-70$ \\
Serum $1,25(\mathrm{OH}) 2 \mathrm{D} 3(\mathrm{pg} / \mathrm{mL})$ & 345 & $21-156$ \\
Cortisol $(\mu \mathrm{g} / \mathrm{dL})$ & 18 & $6.2-19.4$ \\
Free $\mathrm{T4}(\mathrm{ng} / \mathrm{dL})$ & 0.94 & $0.81-1.73$ \\
Thyroid-stimulating hormone $(\mathrm{mU} / \mathrm{L})$ & 1.17 & $0.8-6.25$
\end{tabular}

156). Random urinary calcium/creatinine ratio was high at $1.25(\mathrm{~N}:<0.5)$ and there was nephrocalcinosis in renal ultrasonography. Intravenous hydration with normal saline and furosemide therapy was started on admission, but the serum calcium level remained elevated above the upper normal limit. Consequently, she received an infusion of $0.5 \mathrm{mg} / \mathrm{kg}$ pamidronate-disodium for two doses with no side effects observed, and her serum calcium gradually decreased to $11.3 \mathrm{mg} / \mathrm{dL}$. A chest radiograph demonstrated opacities and interstitial infiltrates; hence, computed tomography of the lungs was performed. This revealed widespread pulmonary opacities and consolidation, multiple calcified lymph nodes and parenchymal mass with cavitary lesions (Fig. 1). The patient was again questioned for contact with anyone with tuberculosis. It was learned that anti-tuberculosis therapy was initiated to the mother at the gestation, but she did not complete the treatment. In addition, the patient was not immunised for bacilli Calmette-Guérin. In view of the severe symptomatology and radiological findings, a diagnosis of a hypercalcemic crisis secondary to tuberculosis was
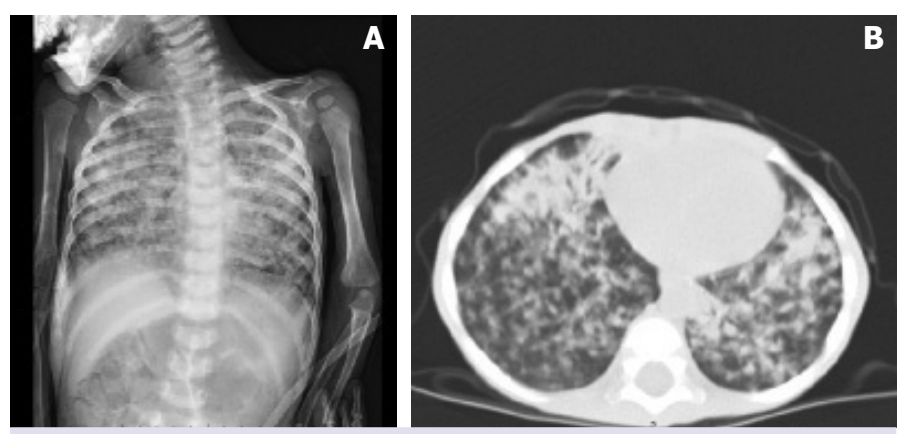

FIGURE 1. Chest radiography and thoracic computed tomography of the patient with pulmonary tuberculosis. (A) The chest radiograph demonstrated opacities and interstitial infiltrates bilaterally. (B) Computed tomography of the lung revealed widespread opacities and confluent consolidation with multiple calcified lymph nodes and parenchymal mass with cavitary lesions bilaterally, with more extensive changes on the left.

defined. The patient was empirically started on treatment for tuberculosis with rifampin, isoniazid (INH), pyrazinamide and ethambutol during the hospital admission. Three weeks after admission, we detected Mycobacterium tuberculosis complex DNA by the polymerase chain reaction in the serum specimen. Within two weeks of the initiation of therapy, the serum calcium level dramatically decreased to $9.1 \mathrm{mg} / \mathrm{dL}$, and the patient showed a markedly improved sense of well-being. Her anti-tuberculosis therapy is continuing without any complaint and a follow-up computed tomography scan showed resolution of her previous lesions in the lung and the hypercalcemia had not recurred again.

\section{DISCUSSION}

Calcium metabolism disturbances are one of the most common metabolic disorders in childhood. Hyperparathyroidism, vitamin $\mathrm{D}$ toxicity, various genetic disorders, malignant diseases and endocrinopathies, such as thyrotoxicosis and Addison's disease, account for the most of cases of hypercalcemia in children. Although the majority is asymptomatic and mostly develops in adults, hypercalcemia is also known to occur in granulomatous diseases, including tuberculosis [1]. The incidence of hypercalcemia in patients with active tuberculosis is thought to be between $6 \%-48 \%$, differs widely between countries because of disparity in vitamin $\mathrm{D}$ and calcium intake and the degree of sunlight exposure, which affects the calcium metabolism. Although in children incidence 
is unknown, symptomatic hypercalcemia in tuberculosis is less common, with rates of $3 \%$ in adults [3].

We also searched a literature review of published cases of hypercalcemia with a diagnosis of tuberculosis in children. There have been only 11 cases of tuberculosis described in the literature resulting in symptomatic hypercalcemia [2, 4-10]. Only two of them had miliary tuberculosis [6, 7]. Hypercalcemia was developed before anti-tuberculosis treatment in seven patients, although developed during the therapy in the other four patients [2, 4-10]. Intravenous fluids, corticosteroids and furosemide were commonly used to resolve the hypercalcemia in most of the patients. In our patient, hypercalcemia did not improve despite intravenous hydration with normal saline and furosemide. However, our patient had a favorable response to pamidronate-disodium with normalization of serum calcium level. Although systemic glucocorticoids are commonly used in the management of severe hypercalcemia, no steroids were administered to our patient because of unknown etiology of hypercalcemia at initial. Besides this, recent studies reveal that pamidronate-disodium is more effective than glucocorticoids in the treatment of children with severe hypercalcemia secondary to vitamin D intoxication or increased vitamin D effects [11, 12]. Therefore, pamidronate-disodium can be an effective alternative to glucocorticoids to treat severe hypercalcemia in patients with a suspicion of tuberculosis.

The mechanism underlying hypercalcemia in tuberculosis is thought to be related to overproduction of $1,25(\mathrm{OH}) 2 \mathrm{D} 3$ by alveolar macrophages [13]. However, tuberculosis-associated hypercalcemia has also been reported in patients with normal and low levels of serum $1,25(\mathrm{OH}) 2 \mathrm{D} 3$ [4]. This situation waiting to be enlightened why some patients develop hypercalcemia with normal or low serum $1,25(\mathrm{OH}) 2 \mathrm{D} 3$ and some none. Although it is not clear supplementation of vitamin D or calcium and excessive sunlight exposure may be the other causes that lead to developing hypercalcemia in tuberculosis [6]. Our case, who had no history of vitamin $\mathrm{D}$ or calcium intake, had an elevated $25-(\mathrm{OH}) \mathrm{D} 3$ and $1,25(\mathrm{OH}) 2 \mathrm{D} 3$. Hence, the cause of the hypercalcemia was attributed to extra-renal 1-alpha hydroxylase activity in the alveolar macrophages.

Severe hypercalcemia, usually considered to be a serum calcium measurement of $14 \mathrm{mg} / \mathrm{dl}$ ( $>3.5$ $\mathrm{mmol} / \mathrm{L})$ is a medical emergency with life-threatening consequences [14]. It is important for clinicians to be familiar with the diagnosis, management and underlying causes of hypercalcemia. This case report emphasizes the rarity of symptomatic hypercalcemia in children with tuberculosis and the difficulties in diagnosis and treatment. Tuberculosis should be systematically considered and investigated in case of hypercalcemia of unknown cause in children even though its rarity. It is, therefore, important to monitor serum calcium and vitamin $\mathrm{D}$ levels periodically in patients with tuberculosis. Additionally, bisphosphonates might be more appropriate treatment options for severe hypercalcemia due to granulomatose disease for two reasons: security for untreated patients before the definitive diagnosis and effective control of calcium levels. However, to draw more meaningful and significant conclusions for the use and efficacy of pamidronate in hypercalcemia related to tuberculosis, research with larger and more data should be conducted. The lack of evidence-based treatment guidelines for such patients may open the way for future studies.

Informed Consent: Written informed consent was obtained from the patient's family for this study and images.

Conflict of Interest: No conflict of interest was declared by the authors.

Financial Disclosure: The authors declared that this study has received no financial support.

Authorship Contributions: Concept - SK; Design - SK, OY; Supervision - SK; Fundings - SE; Materials - OB, ME, SE, DD, OY; Data collection and/or processing - $\mathrm{SK}, \mathrm{OB}, \mathrm{ME}, \mathrm{SE}, \mathrm{DD}$, OY; Analysis and/ or interpretation - SK, OB; Literature review - SK; Writing - SK; Critical review - SK, ME, OY.

\section{REFERENCES}

1. Tebben PJ, Singh RJ, Kumar R. Vitamin D-Mediated Hypercalcemia: Mechanisms, Diagnosis, and Treatment. Endocr Rev 2016;37:521-47.

2. Payne HA, Menson E, Sharland M, Bryant PA. Symptomatic hypercalcaemia in paediatric tuberculosis. Eur Respir Rev 2011;20:53-6. [CrossRef]

3. Chan TY, Chan $\mathrm{CH}$, Shek CC. The prevalence of hypercalcaemia in pulmonary and miliary tuberculosis--a longitudinal study. Singapore Med J 1994;35:613-5.

4. Ayonrinde OT, Zimmerman MJ. Ascites, hypercalcaemia, diffuse peritoneal thickening and elevated OM-MA in a fifteen-year-old girl (a case of peritoneal tuberculosis). Intern Med J 2004;34:216-7. [CrossRef]

5. Gaskin KJ, Vines RH. Hypercalcaemia: an unusual complication of tuberculosis. A case report. Aust Paediatr J 1978;14:44-7. [CrossRef]

6. Gerritsen J, Knol K. Hypercalcaemia in a child with miliary tuberculosis. Eur J Pediatr 1989;148:650-1. [CrossRef]

7. Okascharoen C, Nuntnarumit P, Sirinavin S. Neonatal tuberculosis associated with shock, disseminated intravascular coagulation, hemophagocytic syndrome, and hypercalcemia: a case report. J Perinatol 2003;23:79-81. [CrossRef]

8. Saggese G, Bertelloni S, Baroncelli GI, Di Nero G. Ketoconazole decreases the serum ionized calcium and 1,25-dihydroxyvitamin 
D levels in tuberculosis-associated hypercalcemia. Am J Dis Child 1993;147:270-3. [CrossRef]

9. Saggese G, Bertelloni S, Baroncelli GI, Fusaro C, Gualtieri M. Abnormal synthesis of 1,25-dihydroxyvitamin D and hypercalcemia in children with tuberculosis. Pediatr Med Chir 1989;11:529-32.

10. Tresoldi AT, Pereira RM, Castro LC, Rigatto SZ, Belangero VM. Hypercalcemia and multiple osteolytic lesions in a child with disseminated paracoccidioidomycosis and pulmonary tuberculosis. J Pediatr (Rio J) 2005;81:349-52. [CrossRef]

11. Demir K, Döneray H, Kara C, Atay Z, Çetinkaya S, Çayır A, et al. Comparison of Treatment Regimens in Management of Severe Hyper- calcemia Due to Vitamin D Intoxication in Children.J Clin Res Pediatr Endocrinol 2019;11:140-8. [CrossRef]

12. Kara C, Çetinkaya S, Gündüz S, Can Yılmaz G, Aycan Z, Aydın M. Efficacy and safety of pamidronate in children with vitamin D intoxication. Pediatr Int 2016;58:562-8. [CrossRef]

13. Cadranel JL, Garabédian M, Milleron B, Guillozzo H, Valeyre D, Paillard F, et al. Vitamin D metabolism by alveolar immune cells in tuberculosis: correlation with calcium metabolism and clinical manifestations. Eur Respir J 1994;7:1103-10.

14. Crowley R, Gittoes N. How to approach hypercalcaemia. Clin Med (Lond) 2013;13:287-90. [CrossRef] 